\title{
By Whatever Name
}

\author{
by Svenn-Arve Myklebost
}

"The following is a true story

Only the names have been changed

To protect the guilty"

AC/DC - "It's A Long Way To The Top

(If You Wanna Rock 'n' Roll)” (1975)

MONG the issues that lack fixity in the world of Shakespeare is that of nam-
ing. There are countless cases of uncertainty to do with Shakespearean
names, from the appearance of "ghost" names and variances of spelling to the existence of completely different proper names seemingly belonging to one and the same character. Naming can be counted among those issues that have given editors the power, and sometimes the obligation, to define and shape texts according to a number of ideological, theoretical, methodological, literary and linguistic considerations. Upon investigating decisions made in the realm of naming it should be possible to identify the frameworks that have been constructed to justify the choices that were made, outlining the ideas behind the approaches. How were former editors thinking? What are the implications of their approaches? What may we learn from this?

Names in Shakespearean plays have at least two functions. One is to act as a semiotic marker, grouping certain passages of text, or certain sections of poetry, together, such that we understand that the words connected to a prefix such as IMOGEN (or variations thereof) are expressions usually of one particular voice in the dramatic poem. This has a visual function in that it labels areas of text on the page such that we can, after skimming through a play, ascertain who plays a bigger part and who a smaller. The other function, which is interdependent on the first, is to outline a character or a role, by which I mean, on the one hand, the appearance of a psychologically complex human being, or, on the other, it could have a symbolic function, like an Everyman or a Chorus. Often it can be both. Frequently, the name itself carries symbolic meaning, which will come to bear upon the function of the role/text section. 
Laurie Maguire claims, in her Shakespeare's Names, that onomastics, the science of names,

provides an introduction to the lexical and the local (awareness of etymology, associations, puns on names) and to the intertextual and historical (characters' encounters with cultural baggage of the names they bear: Helen, Theseus, Troilus, Cressida, Henry) and to the theoretical, and feminist (control of language equals control of names equals control of people). ${ }^{1}$

This paper cannot explore all the avenues that Maguire suggests, but it will concentrate its attention on two cases of naming not addressed in Maguire's book (indeed the bulk of the paper was written before I was made aware of its existence): "Falstaff" versus "Oldcastle" and "Innogen" versus "Imogen".

The core concern of the paper is this: if names, and words and sentiments attached to names, are interchangeable, as they have often been in the editing tradition, how do we understand their functions, and how does it concern the editing of the plays?

\section{Case 1: Falstaff! Oldcastle!}

In the introduction to their 1986 Complete Oxford 1 Henry IV, Stanley Wells and Gary Taylor inform us that their edition "restores Sir John's original surname for the first time in printed texts". ${ }^{2}$ That original surname is of course "Oldcastle" instead of the more familiar "Falstaff." The Norton edition, which is based on the Oxford, does not adopt Wells and Taylor's new naming. The Arden2 (which is mentioned because it is included in the collected Arden edition), does not change any names, nor does the most recent Arden, number 3. Wells' and Taylor's decision to reinstate the (surmised) original names of the characters was famously controversial in its time, but that controversy in itself is not what I discuss in this paper. Instead I will try to reconstruct the frameworks of these editors as well as their detractors, reframing their frames, so to speak.

In their General Introduction Wells and Taylor claim that "Shakespeare's work is rooted firmly in the circumstances of its conception and development" while its subsequent impact is "due in great part to that in-built need for constant renewal and adaptation that belongs especially to those works of art that reach full realization only in performance". ${ }^{3}$ However, they find that it is "the texts as they were

1 Laurie Maguire, Sbakespeare's Names (Oxford, Oxford UP, 2007), 4.

2 William Shakespeare, The Complete Works. Ed. Stanley Wells and Gary Taylor (Oxford: Oxford UP, 1986), 509; emphasis mine.

3 Ibid, xiii. 
originally performed that are the sources of his power, and that we attempt here to present with as much fidelity to his intentions as the circumstances in which they have been presented will allow". "These claims tell us two things about the pair's approach to the editing situation. First, they acclaim the importance of change and updating; one can make substantial changes to a Shakespearean text in order to instil it with topical relevance and renewed vitality. This, they claim, is an inevitable mechanic of Shakespeare's enduring influence and popularity. Second, and somewhat paradoxically, they identify the intention of the author as key to "the power" of these texts, and they aim to reproduce these intentions as closely as possible. Further, they identify the intentions and goals of Shakespeare as firmly and primarily theatrical. Thus, their project becomes one of simultaneous fresh renewal and archaeological reconstruction, both aspects contained in the assertion that "for the first time" the "original surname" of Sir John appears in print.

Wells and Taylor's reinstatement of the older name is a historicising attempt to return to something "genuine" and "original", and it does so by undoing an act of censorship. If the Cobham family, the descendants of Sir John Oldcastle, pressured Shakespeare (possibly via the Queen) to change the name, then that was a vile act of repressive governmental interference that has now been mended and abated by the honourable and benevolent Oxford editors, or that at least could be taken to be their attitude.

Accepting, then, for the sake of the argument, that "Oldcastle" should be substituted for "Falstaff," what is to be gained from it? One could argue that if Shakespeare's intention was to allude to the historical Sir Oldcastle, it would make the whole play and the ensuing events of 2 Henry IV and Henry $V$ much darker. However, after having been forced to change the name into Falstaff, Shakespeare would also have to change the story arc of this role in order to avoid further comparisons to the historical Lollard martyr in subsequent usage of the character. Hence, Falstaff could not be hanged in chains and then burned on the gallows like Sir John Oldcastle was in 1417..$^{5}$ Many of Falstaff's compatriots meet grisly ends in France during the events of Henry $V$, but one can only imagine the dramatic, political and emotional impact if it were not Bardolph, but Oldcastle that was hanged in the King's presence, as an echo of the fate of the historical Oldcastle. Can we infer that this was Shakespeare's original plan?

Trying to imagine the events of a hypothetical Henry $V$ in accordance with the framework of the Oxford editors, with its emphasis on history and authorial

4 Ibid, xiii.

5 John Foxe's 1596 Acts and Monuments of Matters Most Speciall and Memorable, Happening in the Church, with an Vniversall History of the Same, widely disseminated during Shakespeare's time, depicts the gruesome hanging in chains and burning of Sir John Oldcastle. Being illustrated it would have been known to literates and illiterates alike. 
intentions, it is not untenable that Shakespeare had a different trajectory in mind for Oldcastle. But any speculation about the matter is futile; even if the character started out as Sir John Oldcastle in 1 Henry IV, it was replaced with Sir Jack Falstaff, who never even appears on stage in Henry $V$. Further, and even without such an execution, an allusion to "Oldcastle" rather than "Falstaff" would have instilled a darker tone into the repudiation scene at the end of 2 Henry IV. Apparently, the historical Oldcastle was on friendly terms with Henry $\mathrm{V}$ before religious and political matters eventually made them mortal enemies. An "Oldcastle" in 1 Henry IV makes the rejection of intimacy for political reasons in 2 Henry IV ring with a tone of seriousness even graver than the one now discernible.

Within the paradigm of Wells' and Taylor's approach (or their frame, if you will), it does indeed make sense to change the name for just one play, because it is possible to argue that Oldcastle's path was altered to such an extent (before it could be trodden) that he is no longer the same character. Falstaff (especially the clownish Falstaff we meet in The Merry Wives of Windsor) is not the same person as 1 Henry IV's Oldcastle. The consequence of there being different names in the different plays is that Falstaff becomes a near-identical substitute, but one with other connotations and a different fate. Strangely, the Oxford editors do not discuss these matters much. In the introduction to 2 Henry IV they simply state that "Shakespeare seems from the start to have accepted the change of Sir John's surname to Falstaff". ${ }^{6}$ It could be argued, however unfashionable it may sound, that it is not just the name that has been changed, but, as I have argued, significant trajectories of plot and interpersonal relationships, in addition, of course, to the aspect I am less interested in for this paper: the historical religious and political implications of the play's Elizabethan topicality. To Wells and Taylor, however, it seems more important to amend the intention/censorship issue than to address the name's formal function within the plays, and how it creates a great gulf between 1 Henry IV and the other plays featuring Falstaff and Hal. The Textual Companion provides no further speculation about Shakespeare's ideas for Oldcastle's role.

David Scott Kastan discusses the matter in Shakespeare After Theory. He comments on Taylor's insistence that "Oldcastle" be returned to 1 Henry IV and the odd fact that it has been returned to the complete Oxford text, but not to David Bevington's individual Oxford edition. According to Kastan, Bevington's decision is a sound one, since Falstaff reappears in other plays that depend on familiarity with the fat knight from 1 Henry $I V$. Bevington considers the knight to be one "fictional entity, requiring a single name. Since that name could no longer be 'Oldcastle,' it had to be 'Falstaff,' in 1 Henry IV, as in the later plays".

6 Shakespeare, The Complete Works, 573.

7 Quoted in David Scott Kastan, Shakespeare After Theory (New York: Routledge, 1999), 95. 
I am not sure that I agree with Bevington's notion that the knight is one fictional entity. There is a multiplicity involved in this matter that cannot be circumvented via wishful thinking. Kastan, however, wishes to retain the Falstaff name for other reasons. In the first place he argues that Oldcastle would not be considered a protestant martyr in the $1590 \mathrm{~s}$, but as a precursor to radical, puritan protestants; a group at odds with the Queen and the government. ${ }^{8}$ So, if the knight were to be re-historicised, Kastan would do so for other reasons than those held by Taylor. Be that as it may, Kastan's primary reason for retaining "Falstaff" is based in his emphasis on text rather than on character - or "what Roland Barthes calls 'the volume of sociality, that the literary text both mediates and transforms". " According to Kastan, Taylor can only see one reason for retaining "Falstaff", namely that it is the more famous name; obviously not a good enough reason for him. "But," writes Kastan, "there is at least one other substantial objection to the restoration: that is, that all the authoritative texts print 'Falstaff' and none prints 'Oldcastle.' 'Oldcastle' may return us to 'Shakespeare's original conception,' but literally 'Oldcastle' is not a 'reading' at all'. ${ }^{10}$ To Kastan, then, the materiality of the text takes precedence over whatever discontinuity may be perceived between the fat knight plays. For Bevington, on his hand, this discontinuity represents a problem which needs to be eliminated: there can only be one fat knight.

The distance from the first play to the others has become evident to us because Shakespeare had to write the other plays. Or so it would seem. After 1 Henry IV he had a popular character on his hands, and there were many strong incentives for it to reappear; Shakespeare had to write something even if bereaved of Oldcastle. Walter Cohen's introduction to the Norton edition of Merry Wives addresses the legend of how the play came about. "According to a later tradition of uncertain veracity, the queen, after seeing 1 Henry $I V$, ordered Shakespeare to write another play about Falstaff - showing him in love, according to an improbable account and to complete it within fourteen days". ${ }^{11}$

Whether this is true or not it indicates that the character had started to take on a life of its own, outside the theatre. Ultimately, however, we cannot know whether Shakespeare intended to write 2 Henry IV, Merry Wives or Henry $V$, when he first conceived the fat knight. All we know is that they were indeed written, performed and printed, and we have them before us today. It is still far from clear in what form the plays should appear before us, however, so I look to another naming issue in the hope that this will shed further light on the relevant editorial practices.

8 Ibid, 101.

9 Ibid, 102.

10 Ibid.

11 William Shakespeare, The Norton Shakespeare. Ed. Stephen Greenblatt et al. (New York: Norton, 1997), 1227. 


\section{Case 2: $\mathbf{M} / \mathbf{N N}$}

Another well-known case of naming problems has to do with Cymbeline's female protagonist. Should her name be Imogen or Innogen? Again, the Oxford editors claim that the traditional name could not have been the original name, hence it should be changed. This time, however, they do not blame censorship, but a simple minim error on behalf of the scribe (assumedly Ralph Crane): in manuscript the letter $\mathrm{m}$ is very similar to nn. Seeing as the name found in Holinshed is spelled "Innogen" and since evidence from other sources (primarily Dr. Simon Foreman's eyewitness account of the play in performance) seems to point in the same direction, Wells and Taylor have, according to the Textual Companion, "restored the form 'Innogen' throughout the play,"12 just as they "restored" Oldcastle's name in 1 Henry IV. Unlike in the case of Oldcastle/Falstaff, the Norton edition readily adopts this name change, and it can be found in other modern editions of Shakespeare, such as the New Cambridge Cymbeline of 1998. In the time of J. M. Nosworthy's 1955 Arden2, ${ }^{13}$ "Imogen" was still the spelling of choice and is how it still stands in the 2001 Arden Complete Works, but according to my sources "Innogen" will be the spelling throughout the forthcoming Arden3, meaning that this is now, more or less, gospel.

This insistence on the $n n$ spelling results in some peculiar claims. In the individual Oxford edition edited by Robert Warren, the protagonist is referred to as "Innogen" throughout the introduction. This includes identifying Ellen Terry as "the most famous Innogen of the nineteenth century,"14 a sentiment which certainly rings odd. The assertion would shock someone like H. H. Furness, whose New Variorum Cymbeline of 1913 (completed shortly before his death, incidentally) sums up the discussions of the names of the play up to that point in time. George Fletcher ${ }^{15}$ is quoted saying, about "Imogen":

it would seem as if the very revolving in his mind of this intended quintessence of feminine beauty and dignity, physical, moral, and intellectual, had caused his inmost and most exquisite spirit to breathe out spontaneously the name of Imogen - a word all nobleness and sweetness, all classic elegance and romantic charm. ${ }^{16}$

12 Stanley Wells and Gary Taylor, A Textual Companion (Oxford: Clarendon, 1987), 604.

13 Even though Nosworthy refers to Furness' New Variorum Cymbeline, and must be familiar with its naming discussions, he never explicitly considers changing any names. See William Shakespeare, Cymbeline. Ed. J. M. Nosworthy (London: Methuen, 1955).

14 William Shakespeare, Cymbeline. Ed. Roger Warren (Oxford: Clarendon, 2008), 6. 15 I have not been able to conclude anything about who this person was. Library catalogues, Google, personal communication and other methods have failed. Bewilderingly, Furness' New Variorum Cymbeline does not come equipped with a bibliography. 16 William Shakespeare, A New Variorum Edition of The Tragedie of Cymbeline. Ed. H. H. Furness (Philadelphia, Lippincott, 1913), 5; annotation to the Dramatis Personae. 
Furness does not comment upon the tone of this assertion, but adds, as a contrast, that he too believes that the name must originally have been Innogen, based on the spelling in Holinshed and in the diary notes of Dr. Forman. Like Wells and Taylor much later, Furness identified the error as the compositor's. For Furness, however, it was unthinkable to change the name: "But at this late day, when from boyhood our heart-strings have been woven around Imogen, to turn to Innogen would make the earth's base seem stubble". ${ }^{17}$ He definitely holds it as intellectually justifiable that the spelling could be changed, but he remains constant in his practice of not changing the spellings of the folio, and in his love for Imogen.

We could speculate at length about this name. It is possible, for instance, that Shakespeare made up the name "Imogen," based on its similarity with the historical "Innogen", but twisting it ever so slightly to resemble Latinate words such as "imitate," "image," "primogenitor" or "primogeniture." According to some websites that deal with names, "Imo gens" means "last born" in the Latin, but I have not been able to get this confirmed by a reliable source (in fact, it seems rather spurious). The word "Primogeniture" on its hand, encapsulates Imogen, in a linguistically playful mood. The presence of anagrams and other linguistic games in Shakespeare has again become a serious object of study (safely removed from the cryptographic, Bacon-was-Shakespeare paradigm), and I would suggest looking to recent work by Alastair Fowler and Christopher Ricks for more in-depth discussions in this field. ${ }^{18}$ This may prove nothing, but it remains a fact that Shakespeare invented many names (and indeed coined many words), some as variations on existing, foreign-sounding names, while some were apparently taken out of thin air (to take an example: no one has yet been able to definitely identify the source of the name of Caliban, probably because there is no definite source, only linguistic echoes of different words and names, such as "carib" and "cannibal"). ${ }^{19}$ Indeed, the inspiration for the name "Falstaff" probably came from another historical figure, namely Sir John Fastolf. If "Fastolf" became "Falstaff" cannot "Innogen" have become "Imogen"?20 If Dr Forman heard "Innogen," could that not be because that name was already familiar to him (if he was acquainted with English history

17 Ibid, 5-6.

18 See for instance Alastair Fowler, "Anagrams," The Yale Review 95, no. 3 (July 2007) and Christopher Ricks, "Shakespeare and the Anagram," Proceedings of the British Academy 121 (2003).

19 See Virginia Mason Vaughan and Alden T. Vaughan's Shakespeare's Caliban: A Cultural History (Cambridge: Cambridge UP, 1993), passim.

20 On a side note I might add that, in my personal opinion, "Falstaff" might be a pun on "The Fall ("failure") of the Staff ("spear", as in Shakespeare)". The failure of Shakespeare was, of course, the whole Oldcastle disaster and acquiescing to his descendants. That it also has connotations to impotence strengthens rather than weakens that particular argument. See Jean E. Howard's introduction to 1 Henry IV for more about Fastolf, in The Norton Shakespeare, 1154. 
through Holinshed or in any other way), so that he heard what he expected to hear? ${ }^{21}$

In sum, we cannot be absolutely certain that Shakespeare intended the name to be "Innogen," but still, editors of the 1980s onwards thought that it must be changed into this surmised original form. This reveals to us a change in editorial practices that has wider implications than the spelling of names. How can you be sure that something is a mistake? When should mistakes be rectified?

For all the sentimental and romantic attachment to Imogen on display in Fletcher's and Furness' accounts of the name, they still make clear something important: what we identify as "being Shakespeare" is not always what Shakespeare wrote (or intended). Instead this points us back to Roland Barthes' "volume of sociality," revealing how this is subject to change over time. What for Fletcher and Furness was a desirable quality in the name Imogen, may for modern critics be considered too soft; a clichéd and old-fashioned notion of femininity, embodied in, for instance, Ellen Terry's nineteenth century stage performances.

In sum, these two examples of name-changing result in some intriguingly incommensurable conclusions. There is very strong evidence that Shakespeare originally intended the fat knight of 1 Henry IV to be named "Oldcastle". That "Imogen" should have been spelled as "Innogen" is not unlikely, but still a lot less certain. It is somewhat surprising, then, that the latter change has been readily adopted by almost everyone, whereas the Oldcastle controversy became just that: a controversy. Some reasons may be guessed at. For one, the Oldcastle name holds much greater political significance (that we are aware of) than Innogen, and it is not wholly unlikely that the controversy surrounding the name-change back in 1986 was intended from the editors' side - for commercial reasons. Seeing as many saw through it, that may have contributed to the ire with which many addressed the issue (see Brian Vickers' 2006 review of the Oxford edition for an example of this). But "Innogen" too may have a political side to it, as suggested above. It is possible that this spelling was silently accepted as symbolical of the new meaning with which the name could be filled: an Innogen liberated from the reception history of Imogen.

\section{Implications; or, What does it matter who's speaking?}

Several fallacies should be apparent in what I have presented now. Obviously, it may not be good scholarly conduct to speculate about 2 Henry IV and Henry $V$, plays that we cannot know for certain that Shakespeare had even considered when he wrote 1 Henry $I V$. Furthermore, it is probably better to dispense with any form of emotional attachment to what should be intellectual issues. That said, it still

21 Maguire does not discuss the naming of Imogen, but upon referring to this character, she does call her "Imogen". See Maguire, Shakespeare's Names, 39. 
remains clear that editorial decisions have wide-ranging consequences, even in the relatively limited field of names. The above also outlines some of the fundamental, seemingly irreconcilable, differences at work in contemporary and earlier Shakespeare editing.

There are, in the main, three approaches to how to solve problems such as the ones described in this paper. Firstly, one may try to identify Shakespeare's intentions, be they theatrical or literary (Taylor and Wells would claim the former, someone like Lukas Erne would possibly claim the latter) or otherwise. In order to do so, one has to form an opinion whether Shakespeare was cautiously pragmatic or underhandedly political, and whether his policies were royalist, papist, radical or neither of the above. How big a role should the biography play in textual matters, if at all? Secondly, one may look at what kind of solution makes the play better, which in its turn sets off a whole number of discussions and judgements of aesthetic value. On what grounds may something be said to be better than something else? Is "Mote" (in A Midsummer Night's Dream) better than "Moth"? "Innogen" echoes "innocence;" "Imogen" is more original, and has other connotations - what lends the name (and the play) the most interesting resonances, and according to whom? Thirdly, one may decide that text and tradition preside, that "Falstaff" has ingrained itself into our collective consciousness over a period of four hundred years, and that all we really have to infer anything from are the Quartos and Folios of the late sixteenth and early seventeenth centuries (in which case "Imogen" should have remained "Imogen").

It seems to me that neither approach is fully satisfactory. One will find it impossible to edit texts with consistency when one is forced to alternate between these approaches. Can we choose the "best" alternative when it may be at odds with what we think Shakespeare intended, or is the "best" alternative what he would have meant? Does tradition make us blind to what is "better," and to intention? Does it really matter what the author intends in any case? Following Kastan's lead by looking to the texts (Folio and Quartos), and the texts only, is in many cases impossible, as editors will know, but going outside the text has its own range of problems.

Today we have countless editions of Shakespeare to choose from. There are the Quartos and Folios, popular editions with or without illustrations and an everincreasing number of scholarly editions and various forms of performance, on stage, in films and in comic books. Maybe this multiplicity of configurations is in fact the best and most fair outcome we can ever hope for?

Svenn-Arve Myklebost

University of Bergen 